Original Article

\title{
Correlation of Thyroid Stimulating Hormone with Homocysteine and Lipid Profile in Hypothyroidism
}

\author{
Aqsa Malik, Attiya Zaman, Kausar Izhar, Yasir Iqbal
}

\section{ABSTRACT}

OBJECTIVE: To correlate levels of thyroid stimulating hormone with plasma homocysteine and lipid profile in hypothyroid patients

METHODOLOGY: This observational study was carried out at Department of biochemistry, Islamic International Medical College, Rawalpindi from March 2016 to Feb 2017. One Hundred Twenty Eight subjects were selected from the medical outpatient department using convenient non probability sampling technique. Age group of 20 to 55 years was the selection criterion whereas any history of diabetes, hypertension, cardiovascular or renal disease was the exclusion criteria. In group I (control) were sixty four healthy volunteers who presented for routine annual medical and physical examination. In group II (patient's group) were 64 subjects who were diagnosed cases of hypothyroidism on the basis of thyroid stimulating hormone (TSH), free T3 (FT3) and T4 (FT4) levels and clinical features. Estimation of lipid profile and homocysteine levels of both groups was carried out and the data was analyzed using SPSS version 21. Descriptive data were given as mean \pm standard deviation (SD). Comparisons between controls and patients groups were performed using independent $t$-test and $p$ values $<0.05$ were considered statistically significant. Pearson correlation coefficients $(r)$ were calculated to quantify the relationship between TSH and other variables.

RESULTS: : Group I (control) $\mathbf{8 2 . 8 1 \%}$ females and $\mathbf{1 7 . 1 8 \%}$ males. In group II (hypothyroid patients) $\mathbf{8 7 . 5 \%}$ females and $12.5 \%$ males. The mean ages of controls and hypothyroid Patients were $33.65 \pm 5.98$ and $35.20 \pm 7.55$ years respectively. There was a significant increase in mean Plasma tHcy, total cholesterol, LDL and serum triglycerides in hypothyroid patients than in control group. There was a significant decrease in mean HDL Cholesterol in hypothyroid patients than in control group. TSH was found to be positively correlated to homocysteine, total cholesterol and low density lipoproteins

CONCLUSION: It was found in our study that TSH is positively related to homocysteine, total cholesterol and low density lipoproteins in hypothyroidism rendering the patients to risk of atherosclerosis.

KEY WORDS: Thyroid Stimulating Hormone, Homocysteine, Hypothyroidism, Lipid Profile

$\begin{aligned} \text { This article may be cited as: } & \text { Malik A, Zaman A, Izhar K, Iqbal Y. Correlation of Thyroid Stimulating Hormone } \\ & \text { with Homocysteine and Lipid Profile in Hypothyroidism. J Liaquat Uni Med Health } \\ & \text { Sci. 2018;17(03):147-51. doi: 10.22442/jlumhs.181730567 }\end{aligned}$

\section{INTRODUCTION}

Hypothyroidism is a disease in which there is deficiency of thyroid hormones. It is thought to be one of the commonest endocrine disorders in the world ${ }^{1}$. Worldwide the estimated prevalence of hypothyroidism is $4-15 \%{ }^{2}$. In India it is assessed to be $10.95 \%{ }^{3}$ while in Pakistan it is reported to be $4.1 \%{ }^{4}$. Thyroid hormones are imperative for development and functions of numerous structures of the body which includes the heart. It is estimated that every year 410 out of 10000 individuals die because of cardiovascular disease in Pakistan ${ }^{5}$. Atherosclerosis is a significant risk factor in cardiovascular disease and hypothyroidism can result to atherosclerosis because of altered lipid metabolism ${ }^{6}$. In addition to this investigators have found homocysteine as an independent risk factor for atherosclerosis ${ }^{7}$. Homocysteine is an amino acid containing sulphur which is derivative of methionine (essential amino acid) demethylation. Homocysteine escalates the likelihood of atherosclerosis by various mechanisms including endothelial dysfunction, endoplasmic reticulum stress, proliferation of smooth muscle cell and aggregation of platelets ${ }^{8}$. Researchers have found elevated serum homocysteine in hypothyroid patients ${ }^{9,10}$. This increase in total homocysteine levels might be the result of two mechanisms either increase total homocysteine formation due to direct effect of thyroid hormone on homocysteine metabolism in the liver or decreased renal total homocysteine clearance.

Thyroid stimulating hormone (TSH) is the first-line investigation to be carried out whenever there is 
suspicion of hypothyroidism. In recent times, elevated levels of TSH are being considered as a possible cause of inducing injury in patients with cardiovascular disease. Many researchers ${ }^{11}$ have reported that elevated levels of TSH are associated with elevated levels of serum lipids but this issue is being debated as others ${ }^{12}$ have not noted such a finding.

While considerable work has been done regarding association of homocysteine and lipid profile with hypothyroidism, studies are lacking to know whether there is any correlation of TSH with serum lipid profile and homocysteine in hypothyroidism. Therefore we aimed to find out homocysteine and lipid profile levels in hypothyroid patients and correlate them with levels of TSH.

\section{METHODOLOGY}

This observational study was carried out at Biochemistry Department of Islamic International Medical College Rawalpindi with the collaboration of Department of Medicine, Pakistan railways hospital from March 2016 to February 2017. Approval from the ethical review committee of the institute was attained before the commencement of the study. An informed verbal and written consent from the patients was taken to participate in the study. Selection of one hundred twenty eight subjects was done from the medical outpatient department using convenient non probability sampling technique. Selection criteria was age group of 20 to 55 years and any gender. Exclusion criteria was any history of diabetes, hypertension, cardiovascular or renal disease. After selection the subjects were divided into two groups. Group I (control) included sixty four healthy volunteers who presented for routine annual medical and physical examination. In group II (patient's group) were 64 subjects who were diagnosed cases of hypothyroidism on the basis of thyroid stimulating hormone (TSH), free T3 (FT3) and T4 (FT4) levels and clinical features.

Five milliliters blood was collected from the median cubital vein of each subject after overnight fasting of 12 hours and was transferred into the serum separator tube (SST). For later identification the tubes were labeled with name, age, gender and medical record number. The estimation of serum homocysteine, $\mathrm{TSH}$, lipid profile and homocysteine levels of both groups was carried out. Thyroid stimulating hormone (TSH) was determined by electrochemiluminescence (ECL) immunoassay (IA) using an Abbott Architect i2000 (Abbott Diagnostics, Abbott Park, IL, USA reference interval 0.4-4.12 $\mathrm{mIU} / \mathrm{L})$. Plasma homocysteine was estimated using an ELISA kit from Cusabio and according to the manufacturer's instructions $(<15 \mu \mathrm{mol} / \mathrm{L}$ normal). Total cholesterol (desirable < $200 \mathrm{mg} / \mathrm{dl}$ ), HDL-Cholesterol (desirable 30-60 mg/dl), LDL-Cholesterol (desirable $<100 \mathrm{mg} / \mathrm{dl}$ ) and triglycerides (desirable $<150 \mathrm{mg} / \mathrm{dl}$ ) were measured with Cobas Dimension RXL Auto analyzer (Germany).

\section{Statistical Analysis}

The collected data was entered in the SPSS version 21 for analysis. Descriptive statistics were applied to measure frequency and percentages of categorical variables like gender and mean with standard deviations for continuous variables like age, homocysteine, TSH and lipid profile. Comparisons between controls and patients groups were performed using independent t-test. $\mathrm{P}<0.05$ was considered as significant. Pearson correlation coefficients $(r)$ were calculated to quantify the relationship between TSH and other variables.

\section{RESULTS}

Group I (control) consisted of $82.81 \%$ females and $17.18 \%$ males. In group II (hypothyroid patients) were $87.5 \%$ females and $12.5 \%$ males. (Table I) The mean ages of controls and hypothyroid patients were $33.65 \pm 5.98$ and $35.20 \pm 7.55$ years respectively. The independent sample t-test was applied to compare the ages and it revealed no significant difference in both the control and hypothyroid group ages and also no age difference within the gender of the two groups. (Table I)

The concentrations of serum Hcy, lipid profile and TSH in hypothyroid and control are presented in Table II. The TSH values were significantly higher in the hypothyroid group (Mean $\pm S D, 12.67 \pm 5.39 \mathrm{mIU} / \mathrm{L}$ vs $1.82 \pm 1.29 \mathrm{mIU} / \mathrm{L} ; 95 \%$ Confidence Interval, respectively; $p<0.05)$. The mean TSH levels of males in the hypothyroid group were $9.29 \pm 1.14 \mathrm{mIU} / \mathrm{L}$ and $11.82 \pm 1.39 \mathrm{mIU} / \mathrm{L}$ in females which were not significantly different. (TABLE III)

There was a significant increase in mean values of Hcy levels in hypothyroid patients than in control group (Mean $\pm S D, 12.67 \pm 2.35 \mu \mathrm{mol} / \mathrm{L}$ vs $3.76 \pm 1.59$ $\mu \mathrm{mol} / \mathrm{L} ;$ 95\% Confidence Interval, respectively; $\mathrm{p}<0.05$ ) (Table II). The mean plasma tHcy of hypothyroid patients was $8.91 \mu \mathrm{mol} / \mathrm{L}$ higher than of control group.

There was a significant increase in mean serum total cholesterol in hypothyroid patients than in control group (Mean \pm SD, $195.25 \pm 10.63 \mathrm{mg} / \mathrm{dl}$ vs $162.05 \pm 17.39 \mathrm{mg} / \mathrm{dl} ; 95 \%$ Confidence Interval, respectively; $p<0.05)$ (Table II). The mean serum total cholesterol of hypothyroid patients was $33.2 \mathrm{mg} / \mathrm{dl}$ higher than of control group.

There was a significant decrease in mean values of HDL-Cholesterol in hypothyroid patients than in control group (Mean $\pm S D, 48.11 \pm 4.62 \mathrm{mg} / \mathrm{dl}$ vs 
$53.85 \pm 6.55 \mathrm{mg} / \mathrm{dl} ; 95 \%$ Confidence Interval, respectively; $p<0.05)$ (Table II). The mean values of HDL-Cholesterol of hypothyroid patients were 5.74 $\mathrm{mg} / \mathrm{dl}$ lower than of control group.

There was a significant increase in mean serum LDL-Cholesterol in hypothyroid patients than in control group (Mean $\pm \mathrm{SD}, \quad 126.79 \pm 22.24 \mathrm{mg} / \mathrm{dl}$ vs $93.70 \pm 14.58 \mathrm{mg} / \mathrm{dl} ; 95 \%$ Confidence Interval, respectively; $p<0.05$ ) (Table II). The mean Serum LDL -Cholesterol of hypothyroid patients was $33.09 \mathrm{mg} / \mathrm{dl}$ higher than of control group.

There was significant increase in mean serum triglyceride in hypothyroid patients than in control group (Mean \pm SD, $111.25 \pm 18.82 \mathrm{mg} / \mathrm{dl}$ vs $140.29 \pm 17.69 \mathrm{mg} / \mathrm{dl} ; 95 \%$ Confidence Interval, respectively; $p<0.05)$ (Table II).

In hypothyroid group, thyroid stimulating hormone was significantly positively related to serum homocysteine $(p=0.000$ and $r=0.508)$, total cholesterol $(p=0.002$ and $r=0.418)$, triglycerides $(p=0.004$ and $r=0.349)$ and low density lipoproteins $(p=0.002$ and $r=0.421)$ whereas it was negatively correlated with $\mathrm{HDL}(p=$ 0.484 and $r=-0.097$ ) which was not significant. (Table III)

TABLE I: DEMOGRAPHIC CHARACTERISTICS OF CONTROL AND HYPOTHYROID PATIENTS

\begin{tabular}{|l|l|c|r|}
\hline & Gender & \multicolumn{1}{c|}{$\begin{array}{c}\text { Age in } \\
\text { years }\end{array}$} & $\begin{array}{c}\text { Gender } \\
\text { distribution }\end{array}$ \\
\hline $\begin{array}{l}\text { Group I Control } \\
(\mathrm{n}=64)\end{array}$ & Male & $32.12 \pm 7.98$ & $17.18 \%$ \\
\cline { 2 - 4 } & Female & $35.45 \pm 8.23$ & $82.81 \%$ \\
\hline \multirow{2}{*}{$\begin{array}{l}\text { Group II Hypo- } \\
\text { thyroid (n=64) }\end{array}$} & Male & $34.65 \pm 9.76$ & $12.5 \%$ \\
\cline { 2 - 4 } & Female & $36.23 \pm 9.44$ & $87.5 \%$ \\
\hline
\end{tabular}

TABLE II: COMPARISON OF CLINICAL

PARAMETERS BETWEEN CONTROL AND HYPOTHYROID PATIENTS

\begin{tabular}{|l|r|r|c|}
\hline $\begin{array}{l}\text { Parameter in } \\
\text { serum }\end{array}$ & $\begin{array}{c}\text { Control group } \\
(\mathbf{n}=64) \\
\text { Mean } \pm \text { SD }\end{array}$ & $\begin{array}{c}\text { Hypothyroid } \\
\text { group }(\mathbf{n}=64) \\
\text { Mean } \pm \text { SD }\end{array}$ & $\begin{array}{c}\mathbf{P} \\
\text { Value }\end{array}$ \\
\hline $\begin{array}{l}\text { Thyroid Stimulating } \\
\text { Hormone (mlU/L) }\end{array}$ & $1.82 \pm 1.29$ & $12.67 \pm 5.39$ & $<0.05$ \\
\hline $\begin{array}{l}\text { Homocysteine } \\
(\mu \mathrm{mol} / \mathrm{L})\end{array}$ & $3.76 \pm 1.59$ & $12.67 \pm 2.35$ & $<0.05$ \\
\hline $\begin{array}{l}\text { Total Cholesterol }(\mathrm{mg} / \\
\mathrm{dl})\end{array}$ & $162.05 \pm 17.39$ & $195.25 \pm 10.63$ & $<0.05$ \\
\hline $\begin{array}{l}\mathrm{HDL}-\text { Cholesterol } \\
(\mathrm{mg} / \mathrm{dl})\end{array}$ & $53.85 \pm 6.55$ & $48.11 \pm 4.62$ & $<0.05$ \\
\hline Triglycerides $(\mathrm{mg} / \mathrm{dl})$ & $111.25 \pm 18.82$ & $140.29 \pm 17.69$ & $<0.05$ \\
\hline $\begin{array}{l}\text { LDL-Cholesterol } \\
(\mathrm{mg} / \mathrm{dl})\end{array}$ & $93.70 \pm 14.58$ & $126.79 \pm 22.24$ & $<0.05$ \\
\hline
\end{tabular}

TABLE III: COMPARISON OF CLINICAL PARAMETERS IN MALE AND FEMALE HYPOTHYROID PATIENTS

\begin{tabular}{|c|c|c|c|}
\hline $\begin{array}{l}\text { Parameter In } \\
\text { Serum }\end{array}$ & $\begin{array}{l}\text { Males }(n=8) \\
\text { Mean } \pm \text { SD }\end{array}$ & $\begin{array}{c}\text { Females } \\
(n=56) \\
\text { Mean } \pm \text { SD }\end{array}$ & $\begin{array}{c}P \\
\text { value }\end{array}$ \\
\hline $\begin{array}{l}\text { Thyroid Stimulating } \\
\text { Hormone (mIU/L) }\end{array}$ & $9.29 \pm 1.14$ & $11.82 \pm 1.39$ & 0.242 \\
\hline $\begin{array}{l}\text { Homocysteine } \\
(\mu \mathrm{mol} / \mathrm{L})\end{array}$ & $10.3 \pm 1.19$ & $11.67 \pm 1.96$ & 0.542 \\
\hline $\begin{array}{l}\text { Total Cholesterol } \\
(\mathrm{mg} / \mathrm{dl})\end{array}$ & $187.35 \pm 11.51$ & $190.29 \pm 10.82$ & 0.814 \\
\hline $\begin{array}{l}\text { HDL-Cholesterol } \\
\text { (mg/dl) }\end{array}$ & $46.83 \pm 2.42$ & $47.92 \pm 6.61$ & 0.919 \\
\hline Triglycerides (mg/dl) & $142.17 \pm 13.12$ & $141.64 \pm 17.16$ & 0.784 \\
\hline $\begin{array}{l}\text { LDL-Cholesterol } \\
(\mathrm{mg} / \mathrm{dl})\end{array}$ & $126.29 \pm 9.61$ & $122.39 \pm 13.14$ & 0.759 \\
\hline
\end{tabular}

TABLE IV:

CORRELATION OF TSH WITH HOMOCYSTEINE AND LIPID PROFILE IN HYPOTHYROID PATIENTS

\begin{tabular}{|l|r|r|}
\hline \multirow{2}{*}{ Parameter in serum } & \multicolumn{2}{|c|}{ Hypothyroidism $(\mathbf{n}=64)$} \\
\cline { 2 - 3 } & $\mathbf{r}$ & \multicolumn{1}{c|}{$\mathbf{P}<$} \\
\hline Homocysteine $(\mu \mathrm{mol} / \mathrm{L})$ & $0.508^{* *}$ & 0.000 \\
\hline Total Cholesterol $(\mathrm{mg} / \mathrm{dl})$ & $0.418^{* *}$ & 0.002 \\
\hline HDL-Cholesterol $(\mathrm{mg} / \mathrm{dl})$ & -0.097 & 0.484 \\
\hline Triglycerides $(\mathrm{mg} / \mathrm{dl})$ & $0.349^{* *}$ & 0.004 \\
\hline LDL-Cholesterol $(\mathrm{mg} / \mathrm{dl})$ & $0.421^{* *}$ & 0.002 \\
\hline
\end{tabular}

tPearson correlation, Correlation is significant at the 0.05 level (2-tailed)

\section{DISCUSSION}

In our study we found hypothyroidism more prevalent in female gender. This prevalence has been reported by Kim YA and according to him the prevalence increases after the age of $60^{13}$. Tunbridge WM 1977 Survey also concluded that TSH levels are increased in females after the age of 45 years ${ }^{14}$ whereas the National Health and Nutrition Survey (NHANES III) established that anti thyroid antibodies tend to increase with age in females ${ }^{15}$

The increased frequency of cardiovascular disease in hypothyroid patients has been recognized due to elevation in the levels of low-density lipoprotein and total cholesterol ${ }^{10}$. In our study we found significantly increased serum total cholesterol (TC) and LDLCholesterol in hypothyroid patients as compared to control. These findings are consistent with outcomes of Duntas LH $2012^{16}$, Bandi A et al ${ }^{17}$ and Díez JJ 
$2014^{18}$. In hypothyroidism the activity of HMG CoA reductase is reduced which decreases total cholesterol levels but our findings were on the contrary. Increase levels of serum low density and intermediate density lipoproteins and decrease rate of biliary cholesterol secretion might have elevated the total cholesterol. The reason postulated is that a decline in low density lipoprotein receptors occurs on liver cells which lead to decreased receptor-mediated catabolism of Low Density Lipoproteins and Intermediate Density Lipoproteins ${ }^{16}$.

In hypothyroidism, the reduced activity of the cholesterol ester transfer protein (CETP) result in reduced transfer of cholesterol esters from HDL to VLDL and hence increasing the HDL cholesterol levels ${ }^{17}$. But our findings were different. We found that HDL cholesterol levels were significantly decreased in hypothyroid patients compared to the control. These findings are in consistent with the results of Pandian BG $2016^{19}$ and Al-Hakeim HK $2009^{20}$ who also report decreased HDL cholesterol in hypothyroid patients.

We found elevated serum triglycerides (TG) levels in hypothyroid patients. This finding is in concordance with the findings of Ali A $2013^{21}$ and Saleh AA $2015^{22}$ who also reported high TG levels in hypothyroidism. The hypothesized reason is a decline in activity of Lipoprotein lipase which in turn causes reduced Triglyceride rich lipoproteins clearance and hence elevated TG levels.

Nowadays relationship of TSH and lipid profile is becoming an area of interest. We found TSH was positively related to total cholesterol, triglycerides and low density lipoproteins. Chin $\mathrm{KY}^{23}$ has indicated an independent relationship between TSH and lipids in his study. According to him the thyroid hormones stimulate gene expression of low-density lipoprotein (LDL) receptor in the liver and enhance LDL clearance which explains the increased LDL and cholesterol levels observed in hypothyroidism. Therefore TSH levels in a suitable range will attain homeostasis of the lipid levels and slow the advancement of atherosclerosis.

Recently the concept has emerged that high TSH levels are adversely affecting atherosclerosis by altering homocysteine metabolism. Saleh AA $2015^{22}$ and Al-Habori MA $2014^{24}$ reported significantly elevated Hcy in hypothyroid patients which is in accordance to our findings. We also noted that TSH is positively correlated to serum homocysteine $(p=$ 0.000 and $r=0.508$ ) similar to thereport by Bamashmoos SA $2013^{25}$. There are two postulated mechanisms of increase in homocysteine levels in hypothyroidism. Either there is a rise in homocysteine formation due to direct effect of thyroid hormone on homocysteine metabolism in the liver or there is decreased in homocysteine clearance from the kidneys. Decreased serum levels of thyroid hormone affect the Hepatic activity of flavoprotein methylenetetrahydrofolate reductase (MTHFR) enzymes vital for remethylation of homocysteine to methionine. Furthermore the conversion of riboflavin to the active coenzyme flavinadeninedinucleotide becomes faulty leading to poor activity of MTHFR and hence increased Hcy levels.

Our study could have been stronger if the sample size was large and was a cohort study. Nevertheless our study identifies the direct effects of TSH on lipid profile and homocysteine and has given a guide map for further research.

\section{CONCLUSION}

It was found in our study that TSH is positively related to homocysteine, total cholesterol, triglycerides and low density lipoproteins in hypothyroidism rendering the patients to risk of atherosclerosis.

\section{REFERENCES}

1. Mullur R, Liu YY, Brent GA. Thyroid hormone regulation of metabolism. Physiol Rev 2014 Apr; 94(2):355-82. doi: 10.1152/physrev.00030.2013.

2. Gyawali P, Takanche JS, Shrestha RK, Bhattarai $P$, Khanal K, Risal $P$, et al. Pattern of thyroid dysfunction in patients with metabolic syndrome and its relationship with components of metabolic syndrome. Diabetes Metab J 2015 Feb; 39(1):6673. doi: $10.4093 / \mathrm{dmj} .2015 .39 .1 .66$

3. Lee CC, Harun F, Jalaludin MY, Heh CH, Othman $R$, Junit SM. Prevalence of c. 2268dup and detection of two novel alterations, c. 670_672del and c. $1186 \mathrm{C}>\mathrm{T}$, in the TPO gene in a cohort of Malaysian-Chinese with thyroid dyshormonogenesis. BMJ open 2015 Jan 5; 5(1):e006121. doi: 10.1136/bmjopen-2014-006121

4. Unnikrishnan AG, Kalra S, Sahay RK, Bantwal G, John M, Tewari N. Prevalence of hypothyroidism in adults: An epidemiological study in eight cities of India. Indian J Endocrinol Metab 2013 Jul-Aug; 17(4):647-52. doi: 10.4103/2230-8210.113755

5. Riaz M, Salman A, Fawwad A, Iqbal Hydrie $M Z$, Ahmadani MY, Basit A, et al. Trends of serum thyrotropin concentration and associated factors in urban Pakistan (Karachi). Int $\mathrm{J}$ Endocrinol Metabol 2009 Mar; 7(1):12-19.

6. Jawa A, Jawad A, Riaz SH, Assir MZ, Chaudhary AW, Zakria $M$, et al. Turmeric use is associated with reduced goitrogenesis: Thyroid disorder prevalence in Pakistan (THYPAK) Study. Indian J Endocrinol Metab 2015 May 1;19(3):347. DOI:10.4103/2230-8210.152768

7. Jamison DT, Summers LH, Alleyne G. Global 
health 2035: a world converging within a generation. Lancet 2013 Dec 7; 382(9908):1898-955. doi: 10.1016/S0140-6736(13)62105-4.

8. Iqbal SP, Dodani S, Qureshi R. Risk factors and behaviours for coronary artery disease (CAD) among ambulatory Pakistanis. J Pak Med Assoc 2004 May; 54(5):261-6.

9. Nelson RH. Hyperlipidemia as a risk factor for cardiovascular disease. Prim Care 2013 Mar; 40 (1):195-211. doi: 10.1016/j.pop.2012.11.003

10. Kahaly GJ. Cardiovascular and atherogenic aspects of subclinical hypothyroidism. Thyroid 2000 Aug; 10(8):665-79.

11. Rhee CM, Brent GA, Kovesdy CP, Soldin OP, Nguyen D, Budoff MJ, et al. Thyroid functional disease: an under-recognized cardiovascular risk factor in kidney disease patients. Nephrol Dial Transplant 2015 May; 30(5): 724-37. doi: $10.1093 / \mathrm{ndt} / \mathrm{gfu} 024$.

12. Ichiki T. Thyroid hormone and vascular remodeling. J Atheroscler Thromb 2016; 23 (3):266-75. doi: 10.5551/jat.32755

13. Kim YA, Park YJ. Prevalence and risk factors of subclinical thyroid disease. Endocrinol Metab (Seoul) 2014 Mar; 29(1):20-29. doi: 10.3803/ EnM.2014.29.1.20

14. Tunbridge WM, Evered DC, Hall R, Appleton D, Brewis M, Clark F, et al. The spectrum of thyroid disease in a community: the Whickham survey. Clin Endocrinol (Oxf) 1977 Dec; 7(6):481-93.

15. McLeod DS, Cooper DS, Ladenson PW, Whiteman DC, Jordan SJ. Race/ethnicity and the prevalence of thyrotoxicosis in young Americans. Thyroid 2015 Jun; 25(6):621-8. doi: 10.1089/ thy.2014.0504

16. Duntas LH, Brenta G. The effect of thyroid disorders on lipid levels and metabolism. Med Clin North Am 2012 Mar; 96(2):269-81. doi: 10.1016/ j.mcna.2012.01.012.

17. Bandi A, Pyadala N, Srivani N, Borugadda R, Maity SN, Ravi Kumar BN, et al. A comparative assessment of thyroid hormones and lipid profile among hypothyroid patients: A hospital based case control study. IAIM 2016; 3(9): 108-114.

18. Díez JJ, Iglesias P. Serum cholesterol and triglyceride levels in diabetic patients with subclinical hypothyroidism. Endocrinol Nutr 2014 Oct; 61 (8):419-25. doi: 10.1016/j.endonu.2014.01.012.

19. Pandian BG, Sireesha P, Ng YP, Parashuram N. Monitoring the Prevalence of Metabolic Syndrome Among Hypothyroid Patients and Assessing the Effect of Anti-Hypothyroid Treatment on it Among the South Indian Population. J Young Pharmacists 2016 Jan; 8(2):104-7. DOI: 10.5530/ jyp.2016.2.8

20. Al-Hakeim HK. Serum Levels of Lipids, Calcium and Magnesium in Women with Hypothyroidism and Cardiovascular Diseases. J Lab Physicians. 2009 Jul - Dec; 1(2):49-52. doi: 10.4103/09742727.59698

21. Ali A, Sattar A, Hameed A, Maryam B. Lipid Profile in Patients of Primary Hypothyroidism. Annals of King Edward Medical University 2013 Jan-Mar; 19(1):29-32. DOI: https:// doi.org/10.21649/akemu.v19i1.475

22. Saleh AA. Lipid profile and levels of homocysteine and total antioxidant capacity in plasma of rats with experimental thyroid disorders. JOBAZ 2015; 72:173-8. Doi. 10.1016/j.jobaz.2015.01.001

23. Chin KY, Ima-Nirwana $S$, Mohamed IN, Aminuddin A, Johari $\mathrm{MH}$, Ngah WZW. The Relationships between Thyroid Hormones and Thyroid-stimulating Hormone with Lipid Profile in Euthyroid Men. Int J Med Sci 2014; 11(4):349-55. doi: 10.7150/ijms.7104

24. Al-Habori MA, Al-Meeri AM, Al-Nuzaily MA, Ali F. Homocysteine Level in Relation to Thyroid Function Tests in Hypothyroid Patients. Asian J Med Pharm Res 2014; 4(2): 101-6.

25. Bamashmoos SA, Al-Nuzaily MA, Al-Meeri AM, Ali $\mathrm{FH}$. Relationship between total homocysteine, total cholesterol and creatinine levels in overt hypothyroid patients. Springerplus 2013 Aug 30; 2:423. doi: 10.1186/2193-1801-2-423.

\begin{tabular}{|ll|}
\hline AUTHOR AFFILIATION: & \\
Dr. Aqsa Malik (Corresponding Author) & Dr. Kausar Izhar \\
Assistant Professor, Department of Biochemistry & Department of Pathology \\
Watim Medical and Dental College, Rawalpindi -Pakistan. & Benazir Bhutto Shaheed Hospital, Rawalpindi-Pakistan. \\
Email: aqzamalik@gmail.com & Dr. Yasir Iqlbal \\
& Associate Professor, Department of Ophthalmology \\
Dr. Attiya Zaman & Watim Medical and Dental College, Rawalpindi-Pakistan. \\
$\begin{array}{l}\text { Department of Biochemistry } \\
\text { Federal Medical College, Islamabad-Pakistan. }\end{array}$ & \\
\hline
\end{tabular}

